\title{
Mind and Body in Charlotte Brontë's Fiction
}

When I first published Charlotte Brontë and Victorian Psychology in 1996, I received what can only be described as a piece of hate-mail. The writer informed me that her book group had been studying the Brontë novels, and so had decided to read my book. The experience was clearly traumatic, since I apparently ruined Brontë for her, and the entire group, for ever more. I was strongly encouraged never to write again, etc. In the age of the internet we have become used to the vicious tweet or blog, but at a time when email was only just coming into being, it clearly took some determination to find out an author and pen a letter. I had expected to upset many Brontë readers, but the vehemence startled me. Why had my heavily researched, scholarly monograph evoked such a reaction? In these days, when we are encouraged to reach out to the public, and to ensure our work has "impact," one could perhaps judge my book to have been a success; it certainly had a profound effect on members of the general public, well beyond what might be expected of an academic monograph, just not in a particularly positive way. The response is instructive, however: it demonstrates the profound personal and emotional engagement which can underpin reading, and also the investment in particular models of interpretation. The two are very closely intertwined, and what I had done, clearly, in challenging the latter, was to disturb the former, and the symbiosis between reading and a sense of selfhood. In a way, the backlash I experienced was a demonstration, in the current day, of the arguments of the book. I had set out to challenge the deeply embedded belief that the Brontës somehow lived and wrote in a social and cultural vacuum; that they were intuitive geniuses who took inspiration from "above" rather than the world of which they were a part. More particularly, I had aimed to show that the models of selfhood in Charlotte Brontë's fiction drew on the social, psychological and economic constructions of the period.

Although the book was finally published in 1996, it was largely written in 1986-87, during a fellowship at the Society for the Humanities, Cornell University (the delay being due to the labour of reducing the manuscript to a third of its original size, and labours of a rather different, maternal, kind). The dates are significant, since the work was written in the context of the rise of feminist theory, Eagleton's materialist Myths of Power (1975) (with its notable lack of attention to gender), and Gayatri Spivak's electrifying "Three Women's Texts and a Critique of Imperialism." The chapter on the female bodily economy was first published in Body/Politics: Women and the Discourses of Science (1990), another book very much of its time, which arose from a conference Mary Jacobus, Evelyn Fox Keller and I ran at Cornell. The dominant influence on my own work was no doubt Foucault, his theories of techniques of power, and the regulation of the body, and his overarching model of discursive economies. Brontë's vision of "the surveillance of the sleepless eye" in Villette seemed to encapsulate both the struggles for power throughout her fiction, and Foucault's model of the internalisation of social control, as outlined in Discipline and Punish.

In my earlier work, George Eliot and Nineteenth-Century Science (1984), I was able to situate Eliot firmly in the context of the social and scientific thought of the time; given Eliot's relationship with $\mathrm{G}$. H. Lewes, and her copious scientific reading, there was no difficulty in establishing such links. Charlotte Brontë, with her fabled isolation, and no apparent interest in science, represented an altogether different challenge. Whilst drawing on Foucault's theories of discourse, I wanted to move beyond ideas of a general textual economy to track precisely how medical and psychological ideas about the female body, for example, or phrenology, might have entered into Brontë's reading, and life within the Haworth community. I was writing, it should be noted, without the aid of Juliet 
Barker's wonderfully detailed biography of the Brontë family (1994), or Heather Glen's superb The Imagination in History (2002), which undertook a similar task of placing Charlotte Brontë within the social and economic context of her time. The germ of the book lay in my interest in Brontë's deployment of phrenology; others had previously noted her use of phrenological language, but had treated it as a "pseudo-science," related to reading bumps on the head. Drawing on powerful materialist work in the history of science, most notably Robert M. Young's Mind, Brain and Adaptation (1970) and Roger Cooter's The Cultural Meaning of Popular Science (1984), I sought to show how phrenology was both the foundation for a materialist theory of mind, and linked in social usage to social and economic ideologies of individualism and self-development. Textual references to phrenology, and use of the faculties, I argued, were fundamentally linked to the power struggles within the text, as characters sought to read the other, whilst keeping themselves illegible. From phrenology my interests moved outward to consider more broadly the intersection of class and gender ideologies, and theories of body and mind, within Brontë's texts.

Research for the book took years, and involved, for example, poring over the minute books in the Keighley Mechanics' Institute (now in the Keighley library), or advertisements for visiting phrenologists held in the Bradford Public Library. An entire summer was spent in the wonderful eighteenth-century subscription Leeds Library, reading through thirty years' worth of the Leeds Mercury and Leeds Intelligencer in original, very dusty, form, whilst music from the clothing shop below (the chief source of income for the library now), punctuated the otherwise tranquil life of the library, which remains scarcely changed since its original inception in 1768, with Joseph Priestley as Secretary. Now both newspapers are available online, with word-searches that would have taken weeks, completed in seconds. Had they been available, however, I imagine I would not then have read the newspapers from cover to cover: I would have missed not only the accounts of local riots, and grinding poverty; or the graphic depictions of rape, murder and insanity, and the intriguing cases of female husbands, but also the ubiquitous, and highly inventive advertisements for quack medicines and texts, whether the "Silent Friend" (to combat male masturbation), or Widow Welch's female pills. The importance of advertisements in popular culture is now well-recognised, but at the time, little attention had been paid to this medium. It was from reading these ads, however, and noting the congruence between their depictions of the different forms of ailment for the male and female body, and the social and economic ideologies of male self-help in the rest of the newspaper, that I was able to map the ways in which such popular depictions of the body worked to reinforce contemporary ideologies of both class and gender, with male self-control set against female powerlessness in the face of her uterine economy. Brontë, I argued, worked both within and against these notions of gendered differentiation in her fiction. Previous discussions of sexuality in Brontë's fiction, such as Gilbert and Gubar's ground-breaking Madwoman in the Attic (1979), or John Maynard's Charlotte Brontë and Sexuality (1984), had tended to be largely ahistoric (with the notable exception of Elaine Showalter's, Female Malady (1985), viewing sexuality as a given, an unproblematic category; my book formed part of the new wave of work looking at the historical construction of forms of sexuality.

One other form of source I used for my work was the collection of the Brontës' own books in the Brontë Parsonage. Given the extent to which these works, and their annotations, now figure in Brontë scholarship, it is startling to reflect that they had previously attracted very little attention. I was, therefore, the first to note that the parsonage copy of Thomas John Graham's Modern Domestic Medicine (1826) no doubt lay behind the naming of Dr John, or to give his full name, Dr 
John Graham Bretton, in Villette. Far beyond the coincidence of names, however, this book, with all its annotations by Patrick Brontë, opened up the intricate world of a Victorian household, with Patrick anxiously scrutinising the bodily and mental health of his family, and recording possible treatments, from remedies for toothache, through to delirium tremens and possible insanity. My research in this area has formed part of the surge of what Roy Porter (1985)termed doing history "from below," with historians and literary critics moving away from a traditional focus on professional medicine and science, to consider how medicine might have been experienced by the patient, and practised in the household, from the use of medical works designed for families, through to recipe books often passed down through generations. During the weeks I spent in the Parsonage working through the collections, I was joined one day by an enthusiastic member of the public who confided to me her theory that the greatness of the Brontës' works stemmed from the fact that they were "all on drugs." Reading through the various remedies for toothache, heachaches, etc, with all their heavy reliance on opium, I was disconcerted to discover that there was at least a kernel of truth in her claim, although not at all in the ways that she had envisaged. For me the research highlighted how strongly theories of body and mind were interwoven in the nineteenth century, and also how sophisticated were their theories of unconscious movements of the mind. Earlier theories of realism and the Victorian novel had been highly constraining in their interpretations of realism; recognition of the complex constructions of mind-body interaction in the period has made possible a new wave of work exploring historical constructions of psychology, and leading through to the recent work in History of Emotions, as seen, for instance, in Thomas Dixon's From Passions to Emotions (2003), or Tiffany Watt-Smith (2015). For my own research, the work on Brontë led directly into the anthology I published with another specialist in the area, Jenny Bourne Taylor, Embodied Selves: An Anthology of Psychological Texts 1830-1890 (1998), which made available for literary and other scholars, key texts on areas such as dreaming and the unconscious, or the sexual body. Recent work by Jill Matus (2009), for example, on trauma in Victorian fiction has extended work on the unconscious, while Togerson (2005), looks explicitly at constructions of the body in the Brontës.

Research for the Brontë book also entailed extensive reading in periodicals of the era, particularly titles such as Blackwoods and Frasers that we know she would have read. The recent movement to massive digitisation of Victorian periodicals has opened up these resources as never before, and has made possible forms of research that were previously only possible with months of research in a well-stocked historical library. As part of my researches into the Brontës' reading, and Mechanics' Institutes, I noted that in addition to the Keighley Mechanics' Institute, to which we know the Reverend Brontë belonged, a Haworth Mechanics' Institute was also set up: a report of the Annual Soiree of 1852 noted that "we were honoured, as usual, by the kind services of the talented authoress of "Jane Eyre", "Shirley", \&c". That "as usual" is tantalising, leaving it opaque how far Charlotte might have been involved on a regular basis; no further work has been done on the Haworth Institute, but it would be worth more detailed exploration. There were female members from its inception, in the late 1840s; the Institute ran classes and lectures, and perhaps most importantly, a reading room which was open five days a week from 1851, taking daily and weekly papers, and a variety of periodicals. The list of titles taken in 1852 included the Leeds Mercury, and Leeds Intelligencer, but also the Manchester Examiner and Times (known for its free trade radicalism), Punch, Household Words, and Chambers's Journal (which Brontë mentions in Shirley, as a periodical Caroline would have loved). With the development of large scale projects in the history 
of reading, such as UK RED, there has been extensive work on individual experiences of reading . The website thebrontes.net, has also compiled an excellent collection of sources for the Brontës' reading (although scholarly care needs to be taken in drawing upon it). There is, however, undoubted room for further explorations into the textual economy within the Haworth parsonage. For my own part, the research I undertook for the Brontë book led directly to the project on 'Science in the Nineteenth-Century Periodical' (www.sciper.org), which sought to answer on a larger scale the question of how constructions of science and medicine had circulated within the Victorian press and amidst different reading publics.

In The Mind of the Child: Child Development in Literature, Science and Medicine, 1840-1900 (2010), I returned to Brontë studies once more - not, it should be said, in an obvious way with extended readings of texts. Rather, the work of the Brontës, and particularly Jane Eyre, provide the inspiration for the framework of the book as a whole. That unforgettable figure of the child Jane, fiercely standing up to her tyrannical Aunt Reed, or defying the bullying Brocklehurst, provided the seed for thinking about constructions of childhood in the nineteenth century, and in particular the emerging psychological and medical theories of child development. Exploring this territory, it became clear to me that Jane Eyre, alongside other texts such as Eliot's Mill on the Floss, had had a major impact not just on the literature that followed, but also on the construction of psychological theories of childhood. From the late 1840 s onwards, medical writers started to focus seriously on the development of the child mind, to view the child as capable of the same complex array of emotions as an adult. Given our general conceptions of the harshness of Victorian childrearing, it was illuminating to discover numerous accounts warning of the dangers and indeed cruelty of leaving a child in the dark, or of scaring it unduly. Jane's experience when locked in the Red Room became an iconic image of the lasting damage that could be inflicted on the child mind. Brontë, Dickens and Eliot opened up new territory both for the novel and the sciences of mind. Other recent studies have extended work in the field, including Claudia Nelson on Precocity (2012), Boehm on Dickens and the Sciences of Childhood (2013), and most recently, Kate Summerscale, with a popular book on a child murderer (2016). The passionate, disruptive child took many forms.

Some texts remain with you through life. In a material sense, this would be for me my childhood copy of Jane Eyre, with its red leather cover, black and white illustrations, and red ribbon page marker, for which I saved for many weeks when in primary school. At a cognitive level, a well-loved book can help to frame early structures of thought and feeling, and the questions we subsequently ask as academics. I am wrestling, at present, with ideas of injustice as perceived by a child, with Jane Eyre, once more, as the originating figure. As readers we inhabit a complex temporality: framed, like our subjects of study, by the era in which we live, but also haunted by the texts of the past. 
Works Cited

Barker, Juliet. The Brontës (London: Weidenfeld and Nicholson, 1994).

Boehm, Katharina. Charles Dickens and the Sciences of Childhood: Popular Medicine, Child Health and Victorian Culture (London: Palgrave Macmillan, 2013).

Cooter, Roger. The Cultural Meaning of Popular Science: Phrenology and the Organization of Consent in Nineteenth-Century Britain (Cambridge: Cambridge University Press, 1984).

Dixon, Thomas. From Passions to Emotions: The Creation of a Secular Psychological Category (Cambridge: Cambridge University Press, 2003).

Eagleton, Terry. Myths of Power: a Marxist Study of the Brontës (London: Routledge and Kegan Paul, 1974).

Foucault, Michel. Discipline and Punish: The Birth of the Prison, trans. A. Sheridan (Harmondsworth: Penguin, 1979).

Gilbert, Sandra and Susan Gubar. The Madwoman in the Attic: The Woman Writer and the Nineteenth-Century Literary Imagination ((New Haven: Yale University Press, 1979).

Glen, Heather. Charlotte Brontë: The Imagination in History (Oxford: Oxford University Press, 2002). Jacobus, Mary, et al, eds. Body/Politics: Women and the Discourses of Science (New York and London: Routledge, 1990).

Matus, Jill. Shock, Memory and the Unconscious in Victorian Fiction (Cambridge: Cambridge University Press, 2009).

Maynard, John. Charlotte Brontë and Sexuality (Cambridge: Cambridge University Press, 1984).

Nelson, Claudia. Precocious Children and Childish Adults: Age Inversion in Victorian Literature (Baltimore: Johns Hopkins University Press, 2012).

Porter, Roy. "The Patient's View: Doing Medical History from Below", Theory and Society 14:2 (1985), 175-198.

Showalter, Elaine. The Female Malady: Women, Madness and English Culture, 1830-1980 (New York: Pantheon, 1985).

Shuttleworth, Sally. George Eliot and Nineteenth-Century Science (Cambridge: Cambridge University Press, 1984).

----- Charlotte Brontë and Victorian Psychology (Cambridge: Cambridge University Press, 1996).

---- $\quad$ The Mind of the Child: Child Development in Literature, Science and Medicine, 1840-1900 (Oxford: Oxford University Press, 2010).

Spivak, Gayatri. "Three Women's Texts and a Critique of Imperialism", Critical Inquiry, 12 (1985). 
Summerscale, Kate. The Wicked Boy: The Mystery of a Victorian Child Murderer (London: Bloomsbury, 2016).

Taylor, Jenny Bourne and Sally Shuttleworth. Embodied Selves: An Anthology of Psychological Texts, 1830-1890 (Oxford: Oxford University Press, 1998).

Togerson, Beth. Reading the Brontë Body: Disease, Desire and the Constraints of Culture (New York: Palgrave Macmillan, 2005).

Watt-Smith, Tiffany. The Book of Human Emotions (London: Profile Books and Wellcome Trust, 2015).

Young, Robert M. Mind, Brain and Adaptation in the Nineteenth Century: Cerebral Localization and its Biological Context from Gall to Ferrier (Oxford: Oxford University Press, 1970). 